CASSOWARY Volume I (1): 47 - 54

ISSN : 2614-8900

E-ISSN : 2622-6545

CProgram Pascasarjana Universitas Papua, https://pasca.unipa.ac.id/

\title{
Nilai Nutrisi Umbi Ubijalar [Ipomoea batatas (L.) Lamb.] yang Dikonsumsi Bayi dan Anak-anak Suku Dani di Distrik Kurulu Kabupaten Jayawijaya
}

The nutritional rate of sweet potato tubers [Ipomoea batatas (L.) Lamb.] consumed by infants and children of Dani tribe in Kurulu District, Jayawijaya

Andrew B. Pattikawa ${ }^{1)}$, Antonius Suparno ${ }^{2)}$ dan Saraswati Prabawardani ${ }^{2 *}$

${ }^{1)}$ Program Studi S2 Ilmu Pertanian Unipa Manokwari

${ }^{2)}$ Fakultas Pertanian Unipa Manokwari

Jalan Gunung Salju, Amban, Manokwari, Kodepos 98314, Papua Barat, Indonesia

*Email : danysaraswati@gmail.com

\begin{abstract}
Sweet potato is an important staple food crop especially for the local people of Central Highlands Jayawijaya. There are many accessions that have always been maintained their existence to enrich the types of consumption. Traditionally, sweet potato accessions were grouped based on the utilization, such as for animal feed, cultural ceremonies, consumption for adults, as well as for for children and infants. This study was aimed to analyze the nutritional value of sweet potatoes consumed by infants and children of the Dani tribe. Chemical analyses were conducted at the Laboratory of PostHarvest Research and Development Center, Cimanggu, Bogor. The results showed that each of 4 (four) sweet potato accessions, which were consumed by infants and children, had diverse nutrient levels. Accession Sabe showed the highest water content $(72.56 \%)$, vitamin C (72.71 mg/100 g), Fe (11.85 mg/100 g), and K levels (130.41 mg / 100 grams). The highest protein content $(1.44 \%)$, fat $(1.00 \%)$, energy (154.43 kkal/100 gram), carbohydrate $(35.47 \%)$, starch $(30.26 \%)$, reducing sugar $(3.44 \%)$, riboflavin $(0.18$ $\mathrm{mg} / 100 \mathrm{~g}$ ), and vitamin A (574.40 grams IU/100) were produced by accession Manis. On the hand, accession Saborok produced the highest content of ash (1.32\%), vitamin E $(28.30 \mathrm{mg} / 100 \mathrm{~g})$, and B-carotene (64.69 ppm). The highest level of crude fiber $(1.81 \%)$ and thiamin $(0.36 \mathrm{mg} / 100 \mathrm{~g})$ were produced by accession Yuaiken.
\end{abstract}

Keywords : Nutrition, Sweet Potatoes, Dani Tribe, Jayawijaya

ABSTRAK : Ubijalar merupakan tanaman penghasil bahan pangan pokok terutama pada masyarakat di Pegunungan Tengah Jayawijaya. Terdapat banyak aksesi ubijalar yang selalu dipertahankan keberadaannya untuk memperkaya jenis-jenis yang dikonsumsi. Berbagai aksesi ubijalar dikelompokkan pemanfaatannya, baik untuk pakan ternak, keperluan adat istiadat, konsumsi orang dewasa, maupun untuk konsumsi bayi dan anakanak. Penelitian ini bertujuan untuk menganalisis nilai nutrisi ubijalar yang dikonsumsi oleh bayi dan anak-anak di kalangan Suku Dani Jayawijaya. Analisis nutrisi dilakukan di Laboratorium Balai Besar Penelitian dan Pengembangan Pasca Panen Cimanggu, Bogor. Hasil penelitian menunjukkan bahwa masing-masing 4 (empat) aksesi ubijalar untuk 
konsumsi bayi dan anak-anak memiliki keunggulan kadar nutrisi. Aksesi Sabe menunjukkan nulai tertinggi untuk kadar air (72,56 \%), vitamin C (72,71 mg/100 gram), $\mathrm{Fe}(11,85 \mathrm{mg} / 100$ gram $)$, dan $\mathrm{K}(130,41 \mathrm{mg} / 100$ gram $)$. Kadar nutrisi tertinggi pada aksesi Manis meliputi protein (1,44 \%), lemak (1,00 \%), energi (154,43 kkal/100 gram), karbohidrat $(35,47 \%)$, pati $(30,26 \%)$, gula reduksi $(3,44 \%)$, riboflavin $(0,18 \mathrm{mg} / 100$ gram), dan vitamin A (574,40 IU/100 gram). Pada aksesi Saborok, nilai nutrisi tertinggi meliputi kadar abu (1,32\%), vitamin E (28,30 mg/100 gram), dan B-karoten (64,69 ppm), sedangkan kadar serat kasar $(1,81 \%)$ dan thiamin tertinggi $(0,36 \mathrm{mg} / 100$ gram $)$ terdapat pada aksesi Yuaiken

Kata kunci : Nutrisi, Ubijalar, Suku Dani, Jayawijaya

\section{PENDAHULUAN}

Ubi jalar selain merupakan pangan sumber karbohidrat, juga kaya vitamin $\mathrm{A}$ dan $\mathrm{C}$ serta mineral terutama zat besi (Fe), fosfor (P) dan kalsium (Ca). Ubijalar juga mengandung protein dan lemak dalam konsentrasi rendah pada umbi, sedangkan daunnya kaya akan protein, vitamin dan mineral (Woolfe, 1992).

Lembah Baliem merupakan lembah terluas di dataran tinggi Papua tepatnya di Kabupaten Jawawijaya, terletak pada ketinggian $1650-1700$ meter di atas permukaan laut dan secara geografis terletak pada posisi $138^{\circ} 30^{\prime}$ BT - $139^{\circ} 30^{\prime} \mathrm{BT}, 34^{\circ} 0^{\prime} \mathrm{LS}-42^{\circ} 0^{\prime} \mathrm{LS}$. Lembah ini terbentang dari barat ke timur dengan panjang sekitar $60 \mathrm{~km}$ dan lebar $16 \mathrm{~km}$ (Widyastuti, 1994). Penduduk asli lembah Baliem (suku Dani) telah menerapkan teknik budidaya ubijalar yang baik, yaitu dengan pembuatan saluran-saluran drainase yang besar secara turun temurun (Brass, 1941, dalam Widyastuti, 1994). Pembudidayaan ubi jalar oleh suku Dani tersebut merefleksikan energi, waktu dan atensi yang dicurahkan untuk memenuhi kebutuhan hidup. Masya-rakat lembah Baliem telah cukup lama beradaptasi dan menggantungkan hidup pada tanaman ubi jalar sebagai pangan pokok. Hal ini ditunjang oleh dukungan faktor ekologi, budaya dan biofisik dalam mempertahankan budidaya tana-man ini.

Sebagai bahan pangan utama, ubijalar merupakan tanaman penting bagi masyarakat Dani di Distrik Kurulu Jayawijaya. Di Distrik Kurulu terdapat 43 jenis aksesi ubijalar yang dimanfaatkan baik untuk makanan bayi dan anak-anak, dewasa, ternak, maupun upacara adat (Logo, 2011). Terdapat pula aksesi ubijalar yang hanya dimanfaatkan untuk diambil daunnya sebagai sayuran. Pengelompokkan aksesi ubi jalar ke dalam berbagai pemanfaatannya tersebut berkaitan dengan pengetahuan tradisional masyarakat setempat. Hingga saat ini penelitian tentang kan-dungan nutrisi berdasarkan pengelom-pokkan pemanfaatan ubi jalar ter-masuk yang dikonsumsi bayi dan anak-anak belum pernah dilakukan.

Penelitian ini bertujuan untuk mengetahui nilai nutrisi 4 (empat) aksesi ubijalar yang terutama dikon-sumsi oleh bayi dan anak-anak Suku Dani di Distrik Kurulu Kabupaten Jayawijaya. Hasil penelitian ini di-harapkan dapat memberikan informasi ilmiah mengenai nilai nutrisi 4 aksesi ubijalar tersebut, sehingga dapat men-jadi pedoman dalam pemberian kon-sumsi bagi bayi dan anak-anak. Selain itu, penelitian ini diharapkan dapat menjadi sumber informasi genetik untuk program pemuliaan ubijalar. 


\section{BAHAN DAN METODE}

Penelitian dilaksanakan selama 3 bulan mulai bulan September sampai dengan bulan Nopember 2011. Sampel tanaman diambil dari kebun ubijalar petani di Distrik Kurulu Kabupaten Jayawijaya. Analisis kadar nutrisi dilaksanakan di Laboratorium Balai Besar Penelitian dan Pengembangan Pasca Panen Kementrian Pertanian, Cimanggu, Bogor, Jawa Barat.

Metode yang digunakan dalam penelitian ini adalah metode deskriptif dengan teknik observasi lapang untuk menentukan aksesi dominan atau aksesi yang banyak dimanfaatkan oleh masyarakat, dan dilanjutkan dengan analisis laboratorium. Terpilih 4 aksesi dominan yang digunakan untuk konsumsi bayi dan anak-anak. Untuk tujuan analisis nutrisi, umbi ubijalar diambil dari tanaman yang telah siap panen. Umbi dibersihkan dari tanah dan kotoran lainnya, selanjutnya dikemas dan dikirim ke laboratorium. Analisis proksimat sampel umbi ubijalar dilakukan sesuai prosedur standar yang ditetapkan oleh AOAC (1990). Analisis kandungan nutrisi umbi meliputi kadar air, abu, protein, lemak, serat kasar, energi, karbohidrat, pati, gula reduksi, thiamin, riboflavin, vitamin $A$, vitamin $C$, vitamin $E$, BCaroten, kadar Fe, dan K.

\section{HASIL DAN PEMBAHASAN}

Kadar nutrisi umbi 4 (empat) aksesi ubijalar untuk konsumsi bayi dan anak-anak disajikan pada Tabel 1.

Kadar air tertinggi terdapat pada aksesi Sabe yaitu 72,56 \%. Kadar air ini lebih rendah dari pada hasil penelitian Hartoyo (2004) dikutip dalam Elisabeth et al. (2007) yaitu 83,3\%. Hal ini dapat disebabkan karena kadar air selain dipengaruhi faktor genetik juga oleh faktor lingkungan. Umbi dengan kadar air tinggi baik untuk bayi dan anak-anak karena memperlancar proses pencernaan. Aksesi ubijalar yang kadar airnya rendah, namun kadar nutrisinya tinggi, agar dengan mudah dikonsumsi oleh bayi dan anak-anak, maka proses pengolahan dapat dilakukan dengan cara pengukusan atau perebusan.

Kadar abu tertinggi terdapat pada aksesi Saborok yaitu 1,32 \%. Barlina (1996) mendapatkan bahwa kadar abu umbi ubijalar berkisar 2,92 - 4,33\% . Kandungan abu di dalam tanaman dipengaruhi oleh faktor lingkungan dan genetik. Abu merupakan sisa hasil pembakaran bahan organik. Dengan demikian abu merupakan sumber mineral yang cukup baik (Suarni et al, 2005), yang umumnya terdiri dari bermacam mineral baik bersumber dari garam organik (okasalat asetat, pektat) maupun garam anorganik (fosfat, karbonat dan sulfat). Mineral diperlukan oleh tubuh dalam jumlah sedikit, namun mineral mempunyai peranan penting dalam proses metabolisme. Namun tingginya kadar abu dapat juga disebabkan oleh adanya reaksi enzimatis yang menyebabkan tingkat putih tepung menurun (Suarni et al, 2005). Kadar abu yang tinggi kurang disukai pada industri tepung karena cenderung memberi warna gelap pada produknya. Semakin rendah kadar abu pada produk tepung maka warna akhir produk dan tingkat kestabilan tepung akan semakin baik (Ambarsari, et al., 2009).

Kandungan protein tertinggi terdapat pada aksesi Manis yaitu 1,44\%. Hasil ini tidak berbeda dengan hasil penelitian Hartoyo (2004) yang dikutip dalam Elisabeth et al. (2007) yaitu sebesar $1,43 \%$, namun lebih rendah dari hasil penelitian Areghero dan Tofinga (2004), yaitu $6.8-8.2 \%$ pada kultivar ubijalar lainnya. Ubijalar kaya akan karbohidrat namun rata-rata kandungan proteinnya rendah. Oleh sebab itu untuk mencukupi kebutuhan protein, kese- 
imbangan konsumsi antara ubijalar sebagai sumber karbohidrat dan tanaman lainnya sebagai sumber protein sangat dianjurkan bagi masyarakat setempat, terutama untuk bayi dan anak-anak hingga remaja karena protein sebagai salah satu makro nutrisi sangat diperlukan tubuh. Fungsi utama protein sebagai zat pembangun pada masa pertumbuhan. Pada masa bayi hingga remaja, kebutuhan protein lebih besar persentasenya dibandingkan dengan pada masa dewasa dan manula. Pada masa dewasa dan manula protein dibutuhkan untuk mempertahankan jaringan-jaringan tubuh dan mengganti sel-sel yang telah rusak.

Kadar lemak tertinggi terdapat pada aksesi Manis yaitu 1,00\%. Hasil ini lebih tinggi dari pada hasil penelitian Hartoyo (2004) yang dikutip dalam Elisabeth et al. (2007) bahwa kadar lemak ubijalar sebesar 0,17 \%. Menurut Islam (2006) kandungan lemak pada umbi ubijalar berkisar antara $0,06 \%$ $0,48 \%$. Lemak berperan sebagai cadangan energi, penghasil asam lemak esensial dan sebagai pelarut vitamin.
Kadar serat kasar tertinggi terdapat pada aksesi Yuaiken, yaitu 1,81\%, lebih tinggi dari pada hasil penelitian Hartoyo (2004) yang dikutip dalam Elisabeth et al. (2007) bahwa kadar serat kasar ubijalar sebesar 1,6\%. Meskipun serat kasar tidak mengandung nutrisi penting tetapi fungsinya sebagai pengatur ekskresi sisa makanan sangat penting. Menurut Piliang (2006) yang dikutip dalam Herminingsih (2010), serat kasar membantu mempercepat ekskresi sisasisa makanan melalui saluran pencernaan. Pemilihan aksesi dengan kandungan serat kasar tinggi bagi bayi dan anak dimungkinkan karena berfungsi untuk menjaga dan melindungi pencernaan bayi dan anak-anak.

Nilai energi tertinggi berdasarkan hasil analisis terdapat pada aksesi Saborok yaitu 154,43 kkal/100 gram. Seluruh aksesi yang digunakan untuk komsumsi bayi dan anak-anak memiliki nilai energi lebih tinggi dari hasil penelitian Hartoyo (2004) yang dikutip dalam Elisabethet al. (2007) yaitu sebesar 71,1kkal/100 gram.

Tabel 1. Kadar air, abu, protein, lemak, serat kasar dan energy pada umbi 4 (empat) aksesi ubijalar yang dikonsumsi bayi dan anak-anak

\begin{tabular}{lcccccc}
\hline \multirow{2}{*}{ Aksesi } & \multicolumn{7}{c}{ Air } & Abu & Protein & Lemak & Serat & Energi \\
& $(\%)$ & $(\%)$ & $(\%)$ & $(\%)$ & Kasar $(\%)$ & $($ Kkal/100g) \\
\hline Saborok & 61,26 & $\mathbf{1 , 3 2}$ & 1,18 & 0,95 & 1,06 & $\mathbf{1 5 4 , 4 3}$ \\
Sabe & $\mathbf{7 2 , 5 6}$ & 0,87 & 1,09 & 0,83 & 1,31 & 110,43 \\
Yuaiken & 62,83 & 1,16 & 0,91 & 0,85 & $\mathbf{1 , 8 1}$ & 148.29 \\
Manis & 61,03 & 1,06 & $\mathbf{1 , 4 4}$ & $\mathbf{1 , 0 0}$ & 1,21 & 153,94 \\
\hline
\end{tabular}

Tabel 2. Kadar karbohidrat, pati, gula reduksi, thiamin, riboflavin dan vitamin A pada umbi 4 (empat) aksesi ubijalar yang dikonsumsi bayi dan anak-anak

\begin{tabular}{lccccc}
\hline \multirow{2}{*}{ Aksesi } & \multicolumn{5}{c}{ Kadar Nutrisi } \\
\cline { 2 - 6 } & $\begin{array}{c}\text { Karbohidrat } \\
(\%)\end{array}$ & $\begin{array}{r}\text { Pati } \\
(\%)\end{array}$ & $\begin{array}{c}\text { Gula Reduksi } \\
(\%)\end{array}$ & $\begin{array}{c}\text { Thiamin } \\
(\mathrm{mg} / 100 \text { gram })\end{array}$ & $\begin{array}{c}\text { Riboflavin } \\
(\mathrm{mg} / 100 \mathrm{gram})\end{array}$ \\
\hline Saborok & 35,29 & 29,71 & 2,21 & $\mathrm{ttd}$ & $7,65.10^{-3}$ \\
Sabe & 24,65 & 20,41 & 2,48 & $\mathrm{ttd}$ & $2,53.10^{-3}$ \\
Yuaiken & 34,25 & 28,93 & 2,82 & $\mathbf{0 , 3 6}$ & 0,07 \\
Manis & $\mathbf{3 5 , 4 7}$ & $\mathbf{3 0 , 2 6}$ & $\mathbf{3 , 4 4}$ & ttd & $\mathbf{0 , 1 8}$ \\
\hline
\end{tabular}

Keterangan $: \operatorname{ttd}=$ tidak terdeteksi 
Aksesi Manis memiliki kadar tertinggi untuk karbohidrat $(35,47 \%)$, pati $(30,26)$, gula reduksi $(3,44 \%)$, riboflavin $(0,18 \mathrm{mg} / 100 \mathrm{~g})$, dan vitamin A (IU/100g) (Tabel 2). Secara umum kadar karbohidrat pada umbi ubijalar sekitar 27,9\% (Dirjen Kesehatan, 2005). Karbohidrat berfungsi sebagai sumber energi untuk pertumbuhan bayi dan anak-anak. Karbohidrat umbi ubijalar juga memiliki indeks glisemik 54 (rendah) sehingga cocok bagi penderita diabetes.

Gula reduksi adalah gula yang mempunyai kemampuan untuk tereduksi. Hal ini dikarenakan adanya gugus aldehid atau keton bebas. Senyawasenyawa yang mengoksidasi atau bersifat reduktor adalah logam-logam oksidator seperti Cu (II). Vitamin B1, yang dikenal juga dengan nama thiamin, merupakan salah satu jenis vitamin yang memiliki peranan penting dalam menjaga kesehatan kulit dan membantu mengkonversi karbohidrat menjadi energi yang diperlukan tubuh untuk rutinitas sehari-hari. Di samping itu, vitamin B1 juga membantu proses metabolisme protein dan lemak. Bila terjadi defisiensi vitamin B1, kulit akan mengalami berbagai gangguan, seperti kulit kering dan bersisik, mengalami gejala penyakit beri-beri, gangguan saluran pencernaan, gangguan jantung, dan mengganggu sistem saraf.

Vitamin B2 (riboflavin) banyak berperan penting dalam metabolism tubuh, sebagai salah satu kompenen koenzimflavin mononukleotida (flavin mononucleotide, FMN) dan flavin adenine dinukleotida (adenine dinucleotide, FAD). Kedua enzim ini berperan penting dalam regenerasi energi bagi tubuh melalui proses respirasi. Vitamin ini juga berperan dalam pembentukan molekul steroid, sel darah merah, dan glikogen, serta menyokong pertumbuhan berbagai organ tubuh, seperti kulit, rambut, dan kuku.

Kadar vitamin E $(28,30 \mathrm{mg} / 100$ g) dan $\beta$-karoten $(64,69 \mathrm{ppm})$ adalah kadar tertinggi yang terdapat pada aksesi Saborok, sedangkan pada aksesi Sabe memiliki kadar tertinggi untuk kadar vitamin $\mathrm{C}(72,71 \mathrm{mg} / 100 \mathrm{~g})$, kadar $\mathrm{Fe}$ $(11,85 \mathrm{mg} / 100 \mathrm{~g})$, dan kadar K $(130,41$ $\mathrm{mg} / 100 \mathrm{~g}$ ) (Tabel 3).

Tabel 3. Kadar vitamin C, vitamin E, $\beta$-karoten, kadar Fe dan kadar K umbi ubijalar untuk konsumsi bayi dan anak-anak

\begin{tabular}{lccccc}
\hline \multicolumn{1}{c}{ Aksesi } & \multicolumn{5}{c}{ Kadar nutrisi } \\
\cline { 2 - 6 } & $\begin{array}{c}\text { Vitamin C } \\
(\mathrm{mg} / 100 \mathrm{~g})\end{array}$ & $\begin{array}{c}\text { Vitamin E } \\
(\mathrm{mg} / 100 \mathrm{~g})\end{array}$ & $\begin{array}{c}\beta \text {-karoten } \\
(\mathrm{ppm})\end{array}$ & $\begin{array}{c}\mathrm{Fe} \\
(\mathrm{mg} / 100 \mathrm{~g})\end{array}$ & $\begin{array}{c}\mathrm{K} \\
(\mathrm{mg} / 100 \mathrm{~g})\end{array}$ \\
\hline Saborok & 25,44 & $\mathbf{2 8 , 3 0}$ & $\mathbf{6 4 , 6 9}$ & 4,21 & 87,11 \\
Sabe & $\mathbf{7 2 , 7 1}$ & 18,76 & 38,81 & $\mathbf{1 1 , 8 5}$ & $\mathbf{1 3 0 , 4 1}$ \\
Yuaiken & 67,22 & 11,24 & 52,44 & 4,52 & 123,86 \\
Manis & 20,47 & 19,68 & 62,98 & 10,50 & 95.16 \\
\hline
\end{tabular}

Vitamin C (asam askorbat) banyak memberikan manfaat bagi kesehatan tubuh. Di dalam tubuh, vitamin C juga berperan sebagai senyawa pembentuk kolagen yang merupakan protein penting penyusun jaringan kulit, sendi, tulang, dan jaringan penyokong lainnya.
Vitamin C merupakan senyawa antioksidan alami yang dapat menangkal berbagai radikal bebas dari polusi di sekitar lingkungan kita. Terkait dengan sifatnya yang mampu menangkal radikal bebas, vitamin $\mathrm{C}$ dapat membantu menurunkan laju mutasi dalam tubuh 
sehingga risiko timbulnya berbagai penyakit degenaratif, seperti kanker dapat dicegah. Selain itu, vitamin C berperan dalam menjaga bentuk dan struktur dari berbagai jaringan di dalam tubuh, seperti otot. Vitamin ini juga berperan dalam penutupan luka saat terjadi pendarahan dan memberikan perlindungan lebih dari infeksi mikroorganisme patogen. Melalui mekanisme inilah vitamin $\mathrm{C}$ berperan dalam menjaga kebugaran tubuh dan membantu mencegah berbagai jenis penyakit. Defisiensi vitamin $\mathrm{C}$ juga dapat menyebabkan gusi berdarah dan nyeri pada persendian. Sebaliknya akumulasi vitamin $\mathrm{C}$ yang berlebihan di dalam tubuh dapat menyebabkan batu ginjal, gangguan saluran pencernaan, dan rusaknya sel darah merah.

Vitamin E berperan dalam menjaga kesehatan berbagai jaringan di dalam tubuh, mulai dari jaringan kulit, mata, sel darah merah hingga hati. Selain itu, vitamin ini juga dapat melindungi paru-paru dari polusi udara. Hal ini terkait dengan kerja vitamin E di dalam tubuh sebagai senyawa antioksidan alami.

B-karoten merupakan salah satu dari 3 prekursor vitamin A selain $\alpha$ karotin dan $\beta$-criptoxanthin dan senyawa $\beta$-karoten, yaitu merupakan komponen pro vitamin A utama pada sebagian besar pangan yang mengandung senyawa karotenoid (van Jaarsveld et al., 2005). Beta karoten merupakan bahan pembentuk vitamin A dalam tubuh, yang berperan penting dalam menjaga kesehatan indera penglihatan (Hasyim dan Yusuf, 2008). Dari hasil analisis, kadar beta karoten tertinggi terdapat pada aksesi Sabe, yaitu sebesar 388,10 ppm. Aksesi Sabe memiliki daging umbi berwarna oranye. Menurut van Jaarsveld et al., (2005) bahwa sumber pro vitamin A terdapat pada buah-buahan dan sayursayuran berwarna kuning dan oranye serta sayuran daun berwarna hijau tua. Ubijalar berdaging umbi oranye merupakan salah satu sumber beta karotin (Eluagu dan Oniwamo, 2010), dan mengandung 20-30 kali lebih $\beta$-karotin dibandingkan dengan beras merah (Woolfe, 1992). Kadar $\beta$-karotin yang terkandung pada kultivar ubi jalar berdaging umbi oranye lebih tinggi dibandingkan dengan warna kuning dan putih (Sebuliba et al., 2001). Berdasarkan hasil analisis kimia oleh Asian Vegetable Research and Development Centre (AVRDC), umbi ubijalar mengandung beta karotin berkisar antara 0-21 $\mathrm{mg} / 100$ gram bobot basah (Villareal dan Lo, 1983). Menurut Woolfe (1992), umbi kultivar ubijalar berwarna oranye dan kuning mengandung B-karoten hingga $4.000 \mu \mathrm{g} / 100 \mathrm{~g}$ (berdasarkan bobot basah), sedangkan kandungan $ß$-karoten pada ubijalar berdaging umbi putih kurang lebih 70 $\mu \mathrm{g} / 100$ gram. Intensitas warna oranye disebabkan oleh kandungan karotenoid (Ameny dan Wilson, 1997) yang merupakan pro vitamin A dan juga berfungsi sebagai antioksidan untuk melawan radikel bebas.

Garam besi merupakan unsur yang sangat penting untuk membentuk hemoglobin, yaitu unsur zat warna yng terdapat dalam darah merah yang berguna untuk mengangkut oksigen dan $\mathrm{CO}_{2}$ dalam tubuh. Haemoglobin adalah ikatan antara protein, garam besi dan zat warna. Enam puluh persen dari zat besi yang ada di dalam tubuh manusia terdapat dalam hemoglobin ini, dan tubuh manusia menggunakan garam besi dengan hemat. Bila terjadi perombakan butir-butir darah merah, maka garam besi yang terlepas akan diambil alih oleh tubuh untuk pembentukan haemoglobin yang baru.

Kalium merupakan mineral yang sangat penting untuk fungsi yang tepat dari semua sel, jaringan, dan organ 
dalam tubuh manusia. Bersama-sama dengan natrium, klorida, kalsium, dan magnesium, kalium berfungsi menjaga keseimbangan elektrolit dalam tubuh. Di samping itu, kalium berperan penting menjaga fungsi jantung dan memainkan peran penting dalam kontraksi otot rangka, dan menjaga fungsi pencernaan.

\section{KESIMPULAN DAN SARAN Kesimpulan}

1. Aksesi Manis memiliki keunggulan terhadap kadar protein $(1,44 \%)$, lemak $(1,00 \%)$, karbohidrat $(34,57 \%)$, pati $(30,26 \%)$, gula reduksi $(3,44 \%)$, riboflavin $(0,18 \mathrm{mg} / 100 \mathrm{~g})$ dan vitamin $\mathrm{A}$ $(574,40 \mathrm{IU} / 100 \mathrm{~g})$.

2. Aksesi Saborok memiliki keunggulan terhadap kadar abu $(1,32 \%)$, energi $(154,43 \mathrm{kkal} /$ $100 \mathrm{~g})$, vitamin $\mathrm{E}(28,30 \mathrm{mg} /$ $100 \mathrm{~g})$ dan B-karoten $(64,69 \mathrm{mg} /$ $100 \mathrm{~g}$ ).

3. Aksesi Sabe memiliki keunggulan terhadap kadar vitamin $\mathrm{C}$ $(72,71 \mathrm{mg} / 100 \mathrm{~g})$ dan kadar $\mathrm{Fe}$ (11,85 mg/100g).

4. Askesi Yaiken memiliki keung gulan untuk kadar thiamin $(0,36$ $\mathrm{mg} / 100 \mathrm{~g}$ ) dan kadar serat kasar $(1,81 \mathrm{mg} / 100 \mathrm{~g})$.

5. Keragaman nilai nutrisi yang ada merupakan alasan sehingga masyarakat Suku Dani Distrik Kurulu tetap mempertahankan keberadaan askesi-aksesi yang ada untuk pemenuhan kebutuhan nutrisi bagi anak-anaknya.

\section{Saran}

1. Pelestarian berbagai aksesi perlu mendapat perhatian penting untuk mendukung ketahanan pangan dan penganekaragaman bahan pangan.

2. Karagaman kadar nutrisi yang ada merupakan sumber genetik penting sebagai dasar perakitan virietas-varietas ubijalar yang baru sehingga diperoleh jenis ubijalar yang unggul.

\section{DAFTAR PUSTAKA}

Ameny, M.A., \& P.W. Wilson. 1997. Relationsip Between Hunter Color Value and $\beta$-Carotene Contents in White Flesh African Sweet Potatoes (Ipomoea batatas Lam.). J.Sci. Food and Agric. 73: 301-306.

Assocciation of Official Analytical Chemist (AOAC). 1990. Official Methods of Analysis of the Assocciation of Official Analytical Chemist. $15^{\text {th }}$ ed. Washington DC.

Barlina, R. 1996. Pengembangan Berbagai Produk Pangan Dari Daging Buah Kelapa Hibrida. Balai Penelitian Tanaman Kelapa dan Palma Lain. ManadoSulawesi Utara.

Herminingsih, A. 2010. Manfaat Serat Dalam Menu Makanan. Universitas Mercu Buana, Jakarta.

Islam, S. 2006. Sweetpotato Leaf: Its Potential Effect on Human Health and Nutrition. J. Food Sci. 71:13-21.

Dirjen Kesehatan. 2005. Departemen Kesehatan Republik Indonesia. Badan Ketahanan Pangan Nasional (BKPN).

Eluagu, E.N., \& I.A. Onimawo. 2010. Effect of Processing on the Mineral Composition and Antinutritional Factors of Orange Fleshed Sweet Potato (Ipomoea BatatasL. Lam.) Flours. Electronic Journal of Environmental, Agricultural and Food Chemistry. 9(6): 10001005. 
Elisabeth, D.A.A., M.A. Widyaningsih, \& I.K. Kariada. 2007. Pemanfaatan Umbi Ubijalar Sebagai Bahan Baku Pembuatan Es Krim. Balai Pengkajian Teknologi Pertanian (BPTP) Bali. Hal. 1-7.

Hasyim, A \& M. Yusuf. 2008. Ubijalar Kaya Antonsianin, Pilihan Pangan Sehat. Sinar Tani Edisi 20. 26 Agustus 2008.

Logo, O. 2011. Deskripsi Morfologi Beberapa Jenis Ubi Jalar (Ipomoea batatas (L.) Lam.) Berdasarkan Pola Pemanfaatan Oleh Suku Dani di Distrik Kurulu Kabupaten Jawawijaya. (Skripsi). Universitas Negeri Papua. Manokwari.

Sebuliba, J.M., E.N. Nsubuga, \& J.H. Muyonga. 2001. Potential of Orange and Yellow Fleshed Sweetpotato Cultivars for Improving Vitamin A Nutrition in Central Uganda. African Crop Science Journal. 9(10): 309-316.

Van Jaarsveld, P.J., M. Faber, S.A. Tanumihardjo, P. Nestle, C.J.
Lombard, \& A.J.S. Benade. 2005. $\beta$-Carotene Rich Orange Fleshed Sweet Potato Improves the Vitamin A Status of Primary School Children Assessed with the Modified-Relative- DoseResponse Test. American Journal of Clinical Nutrition. 81(5), 1080 $-1087$.

Villareal, R.L., \& H.F. Lo. 1983. Utilization of Sweet Potato Germplasm by Plant Breeders.Philippines Journal of Crop Science. 8(3): 113-118.

Widyastuti. C.A. 1994. Peranan Wanita Suku Dani Dalam Mempertahankan Kelangsungan Ubijalar Sebgai Makanan Pokok Di Kabupaten Jayawijaya, Irian Jaya (Studi kasus Desa Asotipo, Kimbim dan Malagai). Edisi khusus Balittan Malang. 3: 353360.

Woolfe, J.A. 1992. Sweet Potato: An Untapped Food Resource. Cambridge University Press. Cambridge, United Kingdom. 